\title{
Different timing of whitefly control and soybean yield
}

\author{
Controle da mosca-branca em diferentes momentos e a produtividade da soja
}

\section{Simone Silva VieiraI Regiane Cristina Oliveira de Freitas Bueno ${ }^{\text {II }}$ Adeney de Freitas Bueno ${ }^{\text {III }}$ Mari Inês Carissimi Boff ${ }^{\mathbf{V}}$ Alysson Luis Gobbi ${ }^{\mathrm{V}}$}

\begin{abstract}
Trials were carried out in Paraúna, Goiás, Brazil, to evaluate the impact of whitefly on soybean yield. The experimental design was a randomized block, with four treatments and four replications $(10 \mathrm{~m} \times 20 \mathrm{~m})$. The treatments were different levels of infestation, managed by applying insecticide at different timing; the control was kept free of insects by weekly insecticide spraying. The number of insects per leaflet was evaluated weekly, and at harvest the yield $\left(\mathrm{kg} \mathrm{ha}^{-1}\right)$ and the weight of 100 seeds $(g)$ were recorded. The soybean was tolerant to whitefly, since only the treatment where nymphs per leaflet reached 136.31 +26.60 (treatment without the use of insecticides) was sufficiently severe to cause yield loss. This loss was likely associated with the sooty mold, caused by the fungus Capnodium sp. that develops in the sugary secretion produced by the whitefly on the surface of plant leaves. Therefore, insecticides should only be sprayed when a whitefly infestation is sufficiently severe to trigger the growth of sooty mold. The relationship between insect number per leaf and the growth of sooty mold still needs to be determined for different soybean cultivars, as well as for different environmental conditions.
\end{abstract}

Key words: Bemisia tabaci, economic threshold, Glycine max, Soybean-IPM.

\section{RESUMO}

Experimentos foram conduzidos em Paraúna, Goiás, Brasil, avaliando o impacto da mosca-branca na produção de soja. $O$ delineamento experimental foi em blocos ao acaso, com quatro tratamentos e quatro repetições $(10 m x$ 20m). Os tratamentos foram diferentes níveis de infestação, obtidos pela aplicação de inseticidas em diferentes momentos; a testemunha foi mantida livre do ataque da praga, aplicandose inseticida semanalmente. $O$ número de insetos por foliolo foi avaliado semanalmente e, na colheita, foi avaliada a produtividade $\left(\mathrm{kg} \mathrm{ha}^{-1}\right)$ e o peso de 100 sementes $(\mathrm{g})$. A soja foi tolerante à mosca-branca, visto que apenas o tratamento em que as ninfas por foliolo atingiram a média de 136,31+26,60 (tratamento sem aplicação de inseticidas) foi severo o suficiente para causar perdas de produtividade. Essa perda foi provavelmente associada à formação de fumagina, causada pelo fungo Capnodium sp., que se desenvolve nas secreções açucaradas produzidas pela mosca-branca na superfície das folhas. Portanto, inseticidas precisam apenas ser aplicados quando a infestação de mosca-branca for severa o suficiente para propiciar a formação de fumagina. Entretanto, a relação entre o número de insetos por folíolo e a formação de fumagina ainda precisa ser determinada para diferentes cultivares, assim como para diferentes condições ambientais.

Palavras-chave: Bemisia tabaci, nível de ação, Glycine max, MIP-Soja.

\section{INTRODUCTION}

The whitefly Bemisia tabaci (Gennadius) (Hemiptera: Aleyrodidae) is a polyphagous pest of agricultural importance throughout the world (PRABHAKER et al., 2005), mainly in tropical and subtropical regions (NAUEN \& DEHOLM, 2005). This pest was formerly of secondary importance for soybean

\footnotetext{
Instituto Agronômico de Campinas, Centro de Fitossanidade, Campinas, SP, Brasil.

"Departamento de Produção Vegetal, Setor Defesa Fitossanitária, Faculdade de Ciências Agrônomicas, Universidade Estadual Paulista (UNESP), Campus Botucatu, Botucatu, SP, Brasil.

II'Embrapa Soja, CP 231, 86001-970, Londrina, PR, Brasil. E-mail: adeney@cnpso.embrapa.br. Autor para correspondência.

${ }^{\mathrm{IV}}$ Universidade do Estado de Santa Catarina (UDESC),Lages, SC, Brasil.

${ }^{v}$ UNESP, Campus Jaboticabal, Jaboticabal, SP, Brasil.
} 
crops, but in recent years in some countries, this species has become a key-pest, reducing yields and increasing costs due to the insecticides used for its control (VIEIRA et al., 2011) without an established Economic Threshold (ET). Therefore, the increase insecticide use and its consequently increase in soybean production costs due to $\boldsymbol{B}$. tabaci infestations is mainly a consequence of this lack of awareness of the number of pests that justifies its control (ET). This had led soybean growers to apply insecticides indiscriminately. Excessive use of insecticides has only worsened the problem with the pest, since it favors the selection of resistant insects to the chemicals used, making the soybean production system unsustainable (PALUMBO et al., 2001).

Thus, within the context of Soybean Integrated Pest Management (Soybean IPM), which is based on the use of a control method, only when necessary, it is important to consider ET. The ET is defined as the number of pests that justifies the use of a control to prevent the pest population from increasing to the Economic Injury Level (EIL) where profits lost occurs (STERN et al., 1959). Consequently, the establishment of the ET is crucial to chemical control (PEDIGO \& HIGLEY, 1996). However, to determine the ET, it is necessary to quantify the damage caused by the pest and the population density that will cause yield reduction (ELLSWORTH \& MARTINEZ CARRILLO, 2001). In the case of B. tabaci, this is a great challenge, due to certain distinctive characteristics of the insect. Among these characteristics are its feeding mode (phloem sucking), its small size, and its capacity to transmit diseases (ELLSWORTH \& MARTINEZCARRILLO, 2001). As a consequence, there is a lack of studies correlating whitefly infestations with soybean yield. Therefore, this study evaluated the impact of different intensities of infestations of B. tabaci on soybean yield, in order to establish the most appropriate timing for insecticide use.

\section{MATERIAL AND METHODS}

Two field trials were carried out in Paraúna, State of Goiás in central Brazil, during the years of 2008 and 2009, with different intensities of whitefly infestation. One sample of insects was collected at the first day of the trials and was identified by PCR-RAPD of genomic DNA as B. tabaci biotype B.

Goiás State is one of the most important regions of soybean cropping in Brazil, the second largest producer worldwide. Soybean cultivar 'P98R31' (maturity group 8.3 and indeterminate growth habit) was sown at the density of 11.5 seeds/linear meter in the first trial (trial 1), which was conducted under lower pest infestation pressure (where even on untreated plots the number of nymph per leaflet was not superior to 47.05 ) compared to trial 2 . The same cultivar and the same sowing density were used in a second trial (trial 2 ), carried out in an area with higher infestation pressure (where on untreated plots the number of nymph per leaflet was 136.31). The row spacing used was $0.5 \mathrm{~m}$ between rows, and the trial sites were irrigated via central pivot. Fungicides and herbicides were applied equally in all trials, according to the cultural practices commonly adopted by local growers (one postemergence application of herbicide, glyphosate, 3 weeks after plant emergence, and three applications of fungicides, tebuconazol + trifloxystrobin, during the soybean reproductive stage).

The experimental design was a randomized block, with four treatments and four replications. Each plot was $10 \mathrm{~m}$ wide and $20 \mathrm{~m}$ long. Since trials were carried out in a field with natural infestation, the choices of the treatment were made accordingly to the natural occurrence of the insect and also taking into consideration that growers usually apply insecticide when 10 nymphs are found per leaflet. Thus, the treatments evaluated varied between both trials (Table 1) but were always two spraying timing; a control plot that was kept free of insects by weekly applications of insecticide [piriproxifen, $25 \mathrm{~g}$ of active ingredient (a.i) ha-1 ${ }^{-1}$, and an infested control treatment without any insecticide spraying. In the area of the first experiment, a lower infestation of whitefly occurred (where even on untreated plots the number of nymph per leaflet was not superior to 47.05), and for that reason the applications of insecticides were performed when the population of B. tabaci reached 10 or 40 nymphs per leaflet. In the second experiment, due to the higher population of the pest (where on untreated plots the number of nymph per leaflet was 136.31), the insecticides were applied when the population reached 60 or 120 nymphs per leaflet (Figures $1 \mathrm{~A}$ and $1 \mathrm{~B}$ ).

The whitefly infestation level in each plot was evaluated weekly, by counting the number of $\boldsymbol{B}$. tabaci nymphs present on 14 leaflets randomly collected from the middle third of the plants, located in the center of each experimental plot. At the end of the season, the average B. tabaci from the whole season for each treatment could also be evaluated. Additionally a visual percentage of leaf canopy coverage by the sooty mold fungus caused by Capnodium sp. was recorded also on a weekly basis. At the end of the crop cycle, the soybeans were harvested separately for each treatment, evaluating productivity $(\mathrm{kg}$ $\mathrm{ha}^{-1}$ ) and the weight of 100 seeds (g) (corrected to $13 \%$ 
Table 1 - Average number of insect per leaflet from whole crop season, soybean yield and seed weight (Mean \pm SE) after chemical control at different times.

\begin{tabular}{|c|c|c|c|}
\hline Treatment & Average $\boldsymbol{B}$. tabaci nymphs leaflet ${ }^{-1}$ & Yield $\left(\mathrm{kg} \mathrm{ha}^{-1}\right)$ & Weight of 100 seeds $(\mathrm{g})$ \\
\hline Weekly control & $6.50 \pm 0.55 c$ & $3,194.84 \pm 309.90^{\mathrm{ns}}$ & $15.29 \pm 1.23^{\mathrm{ns}}$ \\
\hline Without control (untreated) & $26.48 \pm 2.43 \mathrm{a}$ & $2,452.08 \pm 357.00$ & $14.28 \pm 0.73$ \\
\hline Spray with 40 nymphs/leaflet & $14.77 \pm 1.13 b$ & $3,093.83 \pm 76.15$ & $14.81 \pm 0.24$ \\
\hline Spray with 10 nymphs/leaflet & $8.95 \pm 0.57 b c$ & $3,298.51 \pm 121.30$ & $14.16 \pm 0.54$ \\
\hline $\mathrm{CV}(\%)$ & 20.25 & 17.58 & 11.00 \\
\hline $\mathrm{F}$ & 19.64 & 2.08 & 0.42 \\
\hline $\mathrm{P}$ & $<0.0001$ & 0.1738 & 0.7422 \\
\hline & $\begin{array}{l}22.21 \pm 1.63 c \\
\text { cher in }\end{array}$ & ressure) --- & $1437+071^{\text {ns }}$ \\
\hline $\begin{array}{l}\text { Weekly control } \\
\text { Without control (untreated) }\end{array}$ & $\begin{array}{l}22.21 \pm 1.63 \mathrm{c} \\
58.48 \pm 4.45 \mathrm{a}\end{array}$ & $\begin{array}{l}4,992.01 \pm 220.34 \mathrm{a} \\
3,486.88 \pm 193.42 \mathrm{~b}\end{array}$ & $\begin{array}{l}14.3 / \pm 0 . / 1 \\
12.81 \pm 0.22\end{array}$ \\
\hline Spray with 120 nymphs/leaflet & $34.60 \pm 4.05 b$ & $3,963.38 \pm 304.11 \mathrm{ab}$ & $13.93 \pm 0.33$ \\
\hline Spray with 60 nymphs/leaflet & $20.31 \pm 1.32 \mathrm{c}$ & $4,404.18 \pm 384.11 \mathrm{ab}$ & $13.79 \pm 0.35$ \\
\hline $\mathrm{CV}(\%)$ & 16.35 & 14.78 & 7.15 \\
\hline $\mathrm{F}$ & 21.22 & 4.25 & 1.82 \\
\hline $\mathrm{P}$ & $<0.0001$ & 0.0397 & 0.2144 \\
\hline
\end{tabular}

Means followed by the same letter within the column and trial are not statistically different by the Tukey test $(\mathrm{P}>0.05) .{ }^{\mathrm{ns}} \mathrm{Non}-\mathrm{Significant}$ Differences $(\mathrm{P}>0.05)$.

seed moisture). The results were subjected to exploratory analyses to evaluate the assumption of normality of residues, homogeneity of variance of treatments, and additivity of the model, to allow for the ANOVA and the multiple comparisons of means by the Tukey test $(\mathrm{P} \leq 0.05)($ SAS INSTITUTE, 2001).

\section{RESULTS}

In trial 1, carried out under lower pest infestation (Figure 1A), there was no statistically significant difference in yield among the different levels of B. tabaci infestation (Table 1). In this experiment, the highest numbers of B. tabaci occurred at the soybean $\mathrm{R} 3$ reproductive stage, and in the treatment without application of insecticide, the number of nymphs/leaflet reached $47.05 \pm 6.03$, which was statistically similar to the treatment with spraying at 40 nymphs per leaflet (Figure 1A). The pest infestation decreased naturally from stage R3 to R6, even in the treatment where no insecticide was applied and at R6 stage there was no statistical differences among the treatments (Figure 1A) resulting in no yield difference among treatments (Table 1). Similarly to the results for yield $\left(\mathrm{kg} \mathrm{ha}^{-1}\right)$, the weight of 100 seeds $(\mathrm{g})$ was also statistically equal among the treatments (Table 1).

In trial 2, whitefly pressure was higher (Figure 1B) than in the first trial (Figure 1A). The number of $\boldsymbol{B}$. tabaci nymphs per leaflet reached $136.31 \pm 26.60$ in the treatment without insecticide at the $\mathrm{R} 2$ reproductive stage, statistically similar to treatment of spray with 120 nymphs per leaflet (Figure 1B). Similarly to what occurred in trial 1 , the pest population decreased naturally in the second trial, to a population of 15 nymphs per leaflet at the R6 reproductive stage (Figures 1A and 1B) even though the pest outbreak at the treatment without insecticide kept always higher than the other treatments (Figure 1B).

Despite the higher infestation of $\boldsymbol{B}$. tabaci in the second experiment (Figure 1B), the yield differed statistically only between the treatments with weekly application of insecticides and the treatment with no insecticide application (Table 1). In spite of this significant difference in productivity, no differences in the weight of 100 seeds were recorded (Table 1). Notably, there were no statistical differences among the treatment with weekly application of insecticides and the treatments with insecticide application only when the population of the pest reached 60 nymphs per leaflet, or the treatment when the insecticide was sprayed when the population reached 120 nymphs per leaflet (Table 1). Nevertheless, it is important to point out the growth of sooty mold, covering close to $100 \%$ of the surface of bottom leaves, only occurred in the treatment without application of insecticides in the second trial, when the whitefly population was higher.

Ciência Rural, v.43, n.2, fev, 2013. 


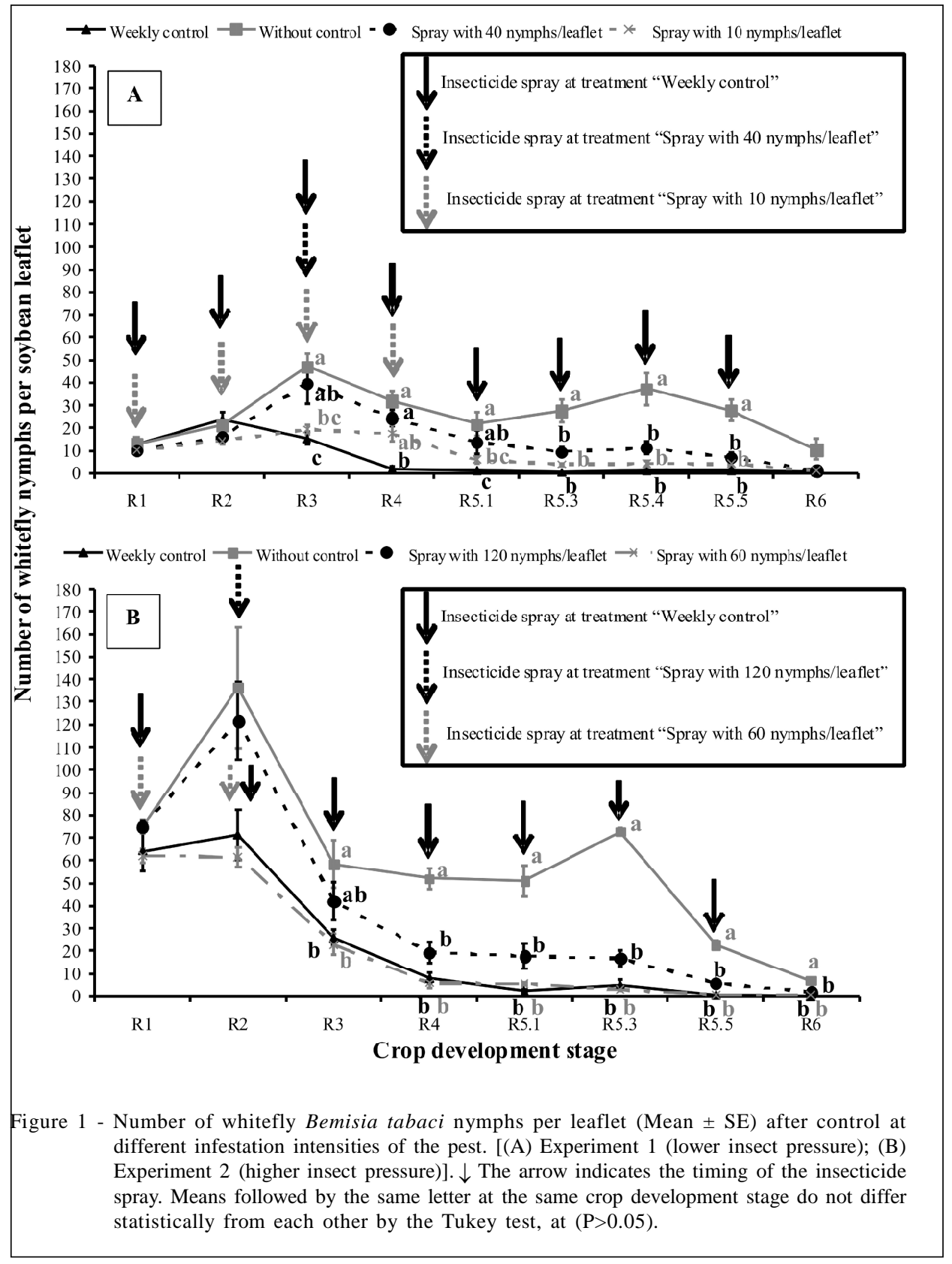

\section{DISCUSSION}

In addition to direct injuries caused by feeding, B. tabaci can also transmit viruses (carlavirus, closterovirus, geminivirus, luteovirus and potyvirus, among others) in several different crops including soybeans (MORALES \& ANDERSON, 2001). On soybean plants, the whitefly is the vector of a virus of the carlavirus group responsible for the disease called soybean stem necrosis. Soybean plants infected with this virus display necrosed stems, which as the symptoms progress may kill the entire plant. This disease was not observed in either trial in this study, most probably because the soybean cultivar 'P98R31' is resistant to the virus. In this context, since soybean cultivars with resistance to 'soybean stem necrosis' are already available; growers can manage this problem by sowing resistant cultivars. This strategy was followed in this study, which focused on evaluating direct damage caused by whitefly feeding. 
In both trials, only whitefly infestation that reached 136.31 nymphs per leaflet (Figure 1B) was sufficiently severe to cause significant yield losses (Table 1). However, it is important to take into consideration that absence of damage might be a cultivar feature that differs among different soybean cultivars (VIEIRAet al., 2011). For example, LAMBERT et al. $(1995,1997)$ observed significant differences in soybean varietal response to whitefly population densities and antixenosis resistance response for the Perrin, Cook, and N88-91 soybean genotypes, compared to the susceptible varieties Braxton and Cobb in field conditions. Therefore, it is important, in future researches, to test other different cultivars with various whitefly infestation intensities, in order to gather this information for as many soybean cultivars as possible.

Among the injuries caused by $\boldsymbol{B}$. tabaci, when the insect occurs in large populations, are the plants weakened by the extraction of large amounts of sap. This induces early defoliation and impacts the soybean plant development and yield, as observed in some soybean fields under attack of this pest (VIEIRA et al., 2011). Another problem is that B. tabaci can cause chlorosis in the leaves of attacked plants, reducing photosynthesis (LIN et al., 1999). However, the number of B. tabaci on the soybean plants that triggers these types of damage is not yet well established. Similarly, there is no clear distinction between the direct effects of the injuries caused by the insect and the indirect effects caused by the growth of sooty mold on the leaves.

The growth of sooty mold on the plant leaves is an indirect consequence of whitefly feeding, since the insect excretes honeydew, a sweet and sticky substance produced in response to excessive feeding on plant sap. When exposed to sunlight, honeydew supports the growth of Capnodium sp., a black fungus called sooty mold, on the leaf surface. Generally, the presence of sooty mold increases the temperature of the leaves and literally "burns" the plant by solar radiation. Sooty mold can also block solar radiation, thus reducing the photosynthesis rate of the leaves (OLIVEIRA et al., 2001). In the present study, sooty mold was detected only on the control treatment of the experiment conducted in the area with higher infestation of the pest (Figure 1B). At $R_{4}$ stage sooty mold appeared covering $20 \%$ of the total leaf surface of all leaves of bottom plant canopy. From $R_{5}$ to $R_{6}$, the fungus increased covering $30 \%$ of the total leaf surface of all leaves of bottom and medium plant canopy and this is probably directly associated with the reduction of productivity observed in that specific treatment (Table 1) since in all the other treatments no sooty mold was observed. After $\mathrm{R}_{6}$ leaves started senescence and sooty mold did not covered more than $30 \%$ of leaf surface. It is important to point out that the Capnodium sp. growing might differ among different plants and climatic conditions. AZEVEDO \& BLEICHER (2002) observed sooty mold growing on melon crops when only 4 to 8 whitefly adults per $2.8 \mathrm{~cm}^{2}$ of foliar area was recorded, number that was then considered ET to start insecticide spraying at that crop. At cotton, only 2.08 whiteflies per leaf were responsible for $30.84 \%$ of yield loss (ALENCAR et al., 2002). Differently, JEON et al. (2009) observed a higher tolerance on cucumber plants when fruit damage only occurred from 63 days after Trialeurodes vaporariorum infestation. This indicates a great variability of plant response to whitefly injury. Therefore, new trials with different soybean cultivars and climatic conditions are also important since this kind of variation in the results might also occur among different soybean cultivars and areas where the crop is cultivated. Nevertheless, our data are the first report on soybean response to whitefly attack and can be taken as a primary result for future researches.

Moreover, B. tabaci probably can also reduce leaf photosynthesis by altering this physiological process in response to its feeding, independently of the growth of sooty mold (PETERSON \& HIGLEY, 1993). Establishing these alterations is an important step in further understanding plant-whitefly interaction. BUENO et al. (2005) reported that 79 B. tabaci adults per soybean plant, at the V2 development stage, were not sufficient to reduce plant photosynthetic capacity. The population size of $\boldsymbol{B}$. tabaci capable of initiating photosynthetic reduction on soybean plants is still unknown, and is one of the challenges for future research in this area.

The determination of the precise relationship between the infestation of a given pest and the consequent loss in crop productivity is the first step in establishing the ET to be used in taking the decision to implement a control method. In this study, the lack of reduction in productivity observed in most of the treatments may also be associated with the natural reduction of the B. tabaci population that occurred along the crop cycle. In addition, the chemical control used to reduce the pest population was highly efficient. In the treatments with insecticide sprays (40 to 120 nymphs leaflet ${ }^{-1}$ ), only a single application was enough to maintain the infestations below these pre-established levels for the experiments, until harvest (Figures 1A and 1B).

The insecticide used, piriproxifen, is a growth regulator, a juvenoide that acts by impairing the normal balance of hormones, resulting in the suppression of 
embryogenesis, metamorphosis, and the formation of the adult insect (DHADIALLA et al., 1998). The efficiency of this insecticide in controlling the whitefly is due to its ovicidal action as well as its high capacity of laminar translocation (PALUMBO et al., 2001). It is possible that in different circumstances than in this study, in longer-enduring infestations, where the injuries caused by the insects remained for a longer period or if another, less efficient insecticide were used, thus allowing a rapid resurgence of the pest, productivity could be more severely affected by the feeding of $\boldsymbol{B}$. tabaci, and sooty mold would be more prevalent (PEDIGO, 1996). These are hypotheses, however, that need to be tested in future studies and do not impair the importance of the results herein reported.

Another important point to take into consideration is that before opting for a control method for the management of a pest, it is essential to determine whether the anticipated cost of the reduction in yield caused by the pest will be higher than the cost of the control method, a parameter that is taken into consideration in the EIL calculation (STERN et al., 1959). Thus, the EIL should be regarded as dynamic and variable in different agricultural conditions, and also the interactions among the components of its definition must be taken into account (PEDIGO et al., 1986). For soybeans, although it varies with different localities and years, the cost of application of piriproxifen is usually higher than the value of one standard bag of soybeans $(60 \mathrm{~kg})$, and this high cost must also be taken into account in deciding on the best time to initiate control.

Many soybean growers are applying insecticide to control whiteflies at low infestation. In Brazil, for example, insecticide spraying usually occurs when 10 nymphs per leaflet are present. Often, this control is decided empirically by field technicians, according to personal perceptions acquired in their field experience. The results obtained here, however, attest that an application based on levels of infestations of 10 nymphs per leaflet is certainly much too early and incurs unnecessary costs and environmental danger. Nevertheless, for a broaden computation of the ET for the whitefly, other experiments could be conducted, to evaluate other factors such as different production systems, different levels of pest infestation and different agro-climate conditions, in addition to the levels of tolerance among different soybean cultivars. As stated above, it is also important to evaluate the correlation between the number of nymphs and the growth of sooty mold, since the occurrence of sooty mold seems to be directly linked to the capacity of the whitefly to reduce the soybean yield.

\section{CONCLUSION}

In conclusion, based on the results obtained here, only whitefly infestations severe enough to trigger the growth of sooty mold would be able to reduce soybean yield and justify the use of insecticides before the fungus becomes widespread. The needless use of insecticides in controlling $\boldsymbol{B}$. tabaci when the number of nymphs is still below the level of 40 nymphs per leaflet should be avoided. It is important to point out that these results are from a single soybean cultivar and therefore is only a preliminary result in this field of research. However, considering the cultivar used and the climatic conditions of the trials (maximum and minimum temperature of $30.8^{\circ} \mathrm{C}$ and $20.3^{\circ} \mathrm{C}$, respectively, and a precipitation of $821.8 \mathrm{~mm}$ ) this is an important result and brings more appropriated economic threshold (ET) for starting insecticide spray on soybean against whitefly outbreaks.

\section{ACKNOWLEDGEMENTS}

The authors are grateful to Conselho Nacional de Desenvolvimento Científico e Tecnológico (CNPq) (process \# 565817/2008-6) and to Coordenação de Aperfeiçoamento de Pessoal de Nível Superior (CAPES) (process \# 23038.035744/ 2008-89).

\section{REFERENCES}

ALENCAR, et al. Nível de dano da mosca-branca no algodoeiro herbáceo. Ciência Agronômica, v.33, p.33-38, 2002.

AZEVEDO, F.R.; BLEICHER, E. Nível de controle para moscabranca, Bemisia argentifolii Bellows \$ Perring na cultura do melão. Ciência Agronômica, v.33, p.25-28, 2002.

BUENO, A.F. et al. Resposta fisiológica de plantas de soja e tomate à injúria causada pela mosca-branca Bemisia tabaci raça B (Hemiptera: Aleyrodidae). Ecossistema, v.30, p.65$70,2005$.

DHADIALLA, T.S. et al. New insecticides with ecdysteroidal and juvenile hormone activity. Annual Review of Entomology, v.43, p.545-569, 1998. Available from: <http:/ /www.annualreviews.org/doi/full/10.1146/annurev.ento. 43.1.545>. Accessed: Jan. 22, 2012. doi: 10.1146/ annurev.ento.43.1.545.

ELLSWORTH, P.C.; MARTINEZ-CARRILLO, J.L. IPM for Bemisia tabaci: a case study from North America. Crop Protection, v.20, p.853-869, 2001. Available from: <http:// w w w. s ciencedirect.com/science/article/pi i/ S0261219401001168>. Accessed: Jul. 2, 2012. doi: 10.1016/ S0261-2194(01)00116-8.

JEON, H.Y. et al. A tentative economic injury level for greenhouse whitefly on cucumber plants in the protective cultivation. Korean Journal of Science and Technology, v.27, p.81-85, 2009. 
LAMBERT, A.L. et. al. Evaluation of selected soybean genotypes for resistance to 2 whitefly species (Homoptera: Aleyrodidae) in the greenhouse. Journal of Entomological Science, v.30, p.519-526, 1995.

LAMBERT, A.L. et al. Field evaluation of fourteen soybean genotypes for resistance to whitefly (Homoptera: Aleyrodidae). Journal of Economic Entomology, v.90, p.658-662, 1997. Available from: <http://esa.publisher.ingentaconnect.com/ content/esa/jee/1997/00000090/00000002/art00060>. Accessed: Jul. 2, 2012. doi: 1997/00000090/00000002/ $\operatorname{art} 00060$.

LIN, T.B. et al. Photosynthesis and productivity of cotton under silverleaf whitefly stress. Crop Science, v.39, p.174184, 1999. Available from: <https://www.crops.org/publications/ cs/abstracts/39/1/CS0390010174>. Accessed: Jul. 2, 2012. doi: 10.2135/cropsci1999.0011183X003900010028x.

MORALES, F.J.; ANDERSON, P.K. The emergence and dissemination of whitefly-transmitted geminiviruses in Latin America. Archives of Virology, v.146, p.415-441, 2001. Available from: <http://www.springerlink.com/content/ 3ebaxxvmhc25ykha/>. Accessed: Jun. 20, 2012. doi: 10.1007/ s007050170153.

NAUEN, R.; DENHOLM, I. Resistance of insect pest to neonicotinoid insecticides: current status and future prospects. Archives of Insect Biochemistry and Physiology, v.58, p.200-215, 2005 .

OLIVEIRA, M.R.V. et al. History, current status, and collaborative research projects for Bemisia tabaci. Crop Protection, v.20, p.709-723, 2001. Available from: <http:// www.sciencedirect.com/science/article/pii/S0261219401 001089>. Accessed: May 16, 2012. doi: 10.1016/S02612194(01)00108-9.

PALUMBO, J.C. et al. Insecticidal control and resistance management for Bemisia tabaci. Crop Protection, v.20, p.739765, 2001. Available from: <http://www.sciencedirect.com/ science/article/pii/S026121940100117X>. Accessed: Jun. 25, 2012. doi: 10.1016/S0261-2194(01)00117-X.
PEDIGO, L.P. General models of economic threshold. In: HIGLEY, L.G.; PEDIGO, L.P. Economic thresholds for integrated pest management. Lincoln, Nebraska, USA: University of Nebraska Press, 1996. p.41-57.

PEDIGO, L.P.; HIGLEY, L.G. Introduction to pest management and thresholds. In: HIGLEY, L.G.; PEDIGO, L. P. Economic thresholds for integrated pest management. Lincoln, Nebraska, USA: University of Nebraska Press, 1996. p.3-8.

PEDIGO, L.P. et al. Economic injury level in theory and practice. Annual Review of Entomology, v.31, p.341-368, 1986. Available from: <http://www.annualreviews.org/doi/abs/ 10.1146/annurev.en.31.010186.002013>. Accessed: Jun. 25, 2012. doi: 10.1146/annurev.en.31.010186.002013.

PETERSON, R.K.D.; HIGLEY, L.G. Arthropod injury and plant gas exchange: current understanding and approaches for synthesis. Entomology (Trends in Agricultural Science), v.1, p.93-100, 1993.

PRABHAKER, N. et al. Assessment of cross-resistance potential to neonicotinoid insecticides in Bemisia tabaci (Hemiptera: Aleyrodidae). Bulletin of Entomological Research, v.95, p.535-543, 2005. Available from: <http:// journals.cambridge.org/action/displayAbstract?fromPage= online\&aid=901224>. Accessed: Jan. 25, 2012. doi: 10.1079/ BER2005385.

SAS INSTITUTE. SAS user's guide: statistics, version 8e. Cary, NC, 2001. 235p.

STERN, V.M. et al. The integrated control concept. Hilgardia, v.29, p.81-101, 1959.

VIEIRA, S.S. et al. Resistance of soybean genotypes to Bemisia tabaci (Genn.) biotype B (Hemiptera: Aleyrodidae). Neotropical Entomology, v.40, p.117-122, 2011. Available from: <http://www.scielo.br/scielo.php?pid=S1519-566X 2011000100018\&script=sci_arttext $>$. Accessed: Jan. 25, 2012. doi: 10.1590/S1519-566X2011000100018. 